\title{
Characteristics of Dissolved Organic Matter Content in Urban Rivers under Different Environmental Impact Zones: A case study of China's Tuo River
}

\author{
Hao Yu ${ }^{1,2}$, Herong Gui ${ }^{2,1 *}$, Yaqi Jiang ${ }^{1,2}$, Zhichun $\mathrm{Li}^{2}$, Meichen Wang ${ }^{1,2}$, \\ Hongxia Fang ${ }^{1,2}$, Chunlei Wang ${ }^{1,2}$, Chen Chen ${ }^{1,2}$, Huili Qiu ${ }^{2}$, Yaru Zhang ${ }^{2}$ \\ ${ }^{1}$ School of Earth and the Environment, Anhui University of Science and Technology, Huainan, China \\ ${ }^{2}$ National Engineering Research Center of Coal Mine Water Hazard Control (Suzhou University), Suzhou, China
}

Received: 27 December 2019

Accepted: 23 February 2020

\begin{abstract}
Although urbanization has significant effects on the landscape around the rivers, there are few studies on the fluorescence characteristics of dissolved organic matter (DOM) in watersheds under different landscape models. Therefore, in this study the optical properties of DOM in the same river under different environmental impact zones as the research object, by fluorescence excitation-emission matrix (EEM) combine with the parallel factor analysis (PARAFAC) method and mathematical statistics to research the tourist, residential and agricultural impact. The results show that agriculture has a significant effect on the concentrations of total nitrogen (TN) and chemical oxygen demand (COD) in the surface water; terrestrial humic-like and two protein-like component were derived using the PARAFAC modeling on sample fluorescence spectra, and significant differences fluorescent components in a river under different environmental impact zones. Fluorescence index analysis showed that autochthonous was the main sources of DOM. Correlation and principal component analysis (PCA) were applied to assess the relationships of fluorescent components, fluorescent indices, and water quality parameters. It revealed agricultural non-point source and the impact of human activities on the watershed.
\end{abstract}

Keywords: Tuo River, water quality, fluorescence indices, environmental impact zone

*e-mail: guiherong@163.com 


\section{Introduction}

Dissolved organic matter (DOM) plays a fundamental role in carbon biogeochemical cycling and evolution of water quality in ecosystems [14] as it can provide nutrients and energy for aquatic microbes, and provide electron acceptors for redox reactions. Therefore, it is related to the migration and transformation of the migration of pollutants [5]. The quality and quantity of DOM in aquatic ecosystems can be heavily influenced by anthropogenic activities $[6,7]$. With the rapid development of urbanization, and the intensity of human activities such as agricultural non-point source pollution, domestic sewage and industrial wastewater discharge on the urban watershed is increasing, which leads to the deterioration of water quality [7, 8]. Differences in land-use types and riverside environments can lead to different characteristics of DOM content in aquatic ecosystems [9, 10], such as agricultural increased catchment DOM concentrations and humic-like substances [9, 11]. Urbanization is strongly connected to changing the type of land use, and many studies have indicated that different land use will lead to various pollution characteristics [6, 12-14]. The composition of DOM in the watershed is restricted by pollutants from different sources, which determines the organic composition of DOM. Therefore, DOM carries information about various pollution sources $[15$, 16], which is the scientific basis for analyzing water pollution sources with the fluorescence characteristics of DOM.

In recent years, many scholars have carried out a lot of research on the composition and source of DOM and its correlation with various influence factors. Yang et al. [17] studied general water quality indices and PARAFAC compositions in four independent watersheds in Ningbo, Zhejiang Province, China. The results of this study demonstrate that the EEMsPARAFAC technique can provide an effective tool to policy makers. Graeber et al. [9] sampled headwater streams draining agricultural and near-pristine catchment to research the characteristics of DOM, indicating that concentrations of dissolved organic carbon were significantly higher for agricultural and wetland catchments than forested catchments. Kulkarni et al. [18] studied the effects of $\mathrm{pH}$ on the optical properties of DOM in high and low arsenic groundwater and surface water, providing a basis for understanding the structure and biogeochemical properties of DOM in these environments. Margot et al. [19] examined DOM properties based on the optical absorbance and fluorescence from 34 Estonian lakes and found that land cover, soil, and catchment hydrology and geology had substantial effects the characteristics in lakes.

However, there are few studies on the relationship between dissolved organic matter (DOM) content and the quality of water in urban rivers under different environmental impact zones. Therefore, in this study we selected the typically urban Tuo River in Suzhou
City, Anhui Province as the research object, and collected river water samples using a three-dimensional fluorescence spectrum combined with parallel factor analysis model to analyze the DOM content of urban rivers under different environmental impact zones.

\section{Materials and Methods}

\section{Study Area}

The Tuo River originates in Shangqiu City, Henan Province, and is the left-bank of the Huaihe River. After flowing through Suixi County and Suzhou City of Anhui Province, it finally flows into Hongze Lake, with a total length of $243.1 \mathrm{~km}$, water depth of $0.5 \sim 1.5 \mathrm{~m}$ during the dry season, a flood period of $5 \sim 6 \mathrm{~m}$, and an average annual flow of river water of $3.52 \sim 72.10 \mathrm{~m}^{3} / \mathrm{s}$. The Tuo passes through the city of Suzhou and is a typical urban river. The direction of the water flow is from northwest to southeast, and the south is an urban area. The northern environment is complex.

This paper is based on the characteristics of the environment surrounding the Tuo River section of Suzhou, to partition the environment around the Tuo River (Figure 1). The upper reaches of the Tuo have been opened into an ecological park (Delta Park), and its environmental impact zone is a "tourism-affected zone" (referred to as "tourist zone", code-named A1) covering an area of $1,533,180 \mathrm{~m}^{2}$, with a core area of about 10,132,32 $\mathrm{m}^{2}$, and water area of about $539,946 \mathrm{~m}^{2}$. The middle reaches are mostly urban residential concentrated residential areas and a small number of factories, with a total length of about $7.5 \mathrm{~km}$, and the environmental impact zone is "residential impact zone" (referred to as "uptown", code-named A2). Downstream is mostly farmland planting area with a total length of about $9.5 \mathrm{~km}$, and the environmental impact of partition is an "agriculture-affected zone" (referred to as "farmland", code-named A3). The Tuo mainly receives direct recharge of atmospheric rainfall and also receives infiltration replenishment of shallow groundwater during dry seasons.

\section{Sampling and Testing}

In July 2019, we specifically conducted the study at this time because in July the rainy season can reflect the influence of a surrounding environment on river water quality. A total of 27 surface water samples were collected from three different environmental impact zones (A1, A2 and A3) in the Suzhou section of the Tuo River. The sampling points are shown in Fig. 1. Water samples were collected from the middle of the river into a clean brown glass bottle (we washed the glass bottles three times with deionized water and water samples before sampling). Sampling points are all GPS positioned, and a pH meter (ST20 Ohaus, Shanghai, China) and dissolved oxygen analyzer (ST300D Ohaus, 


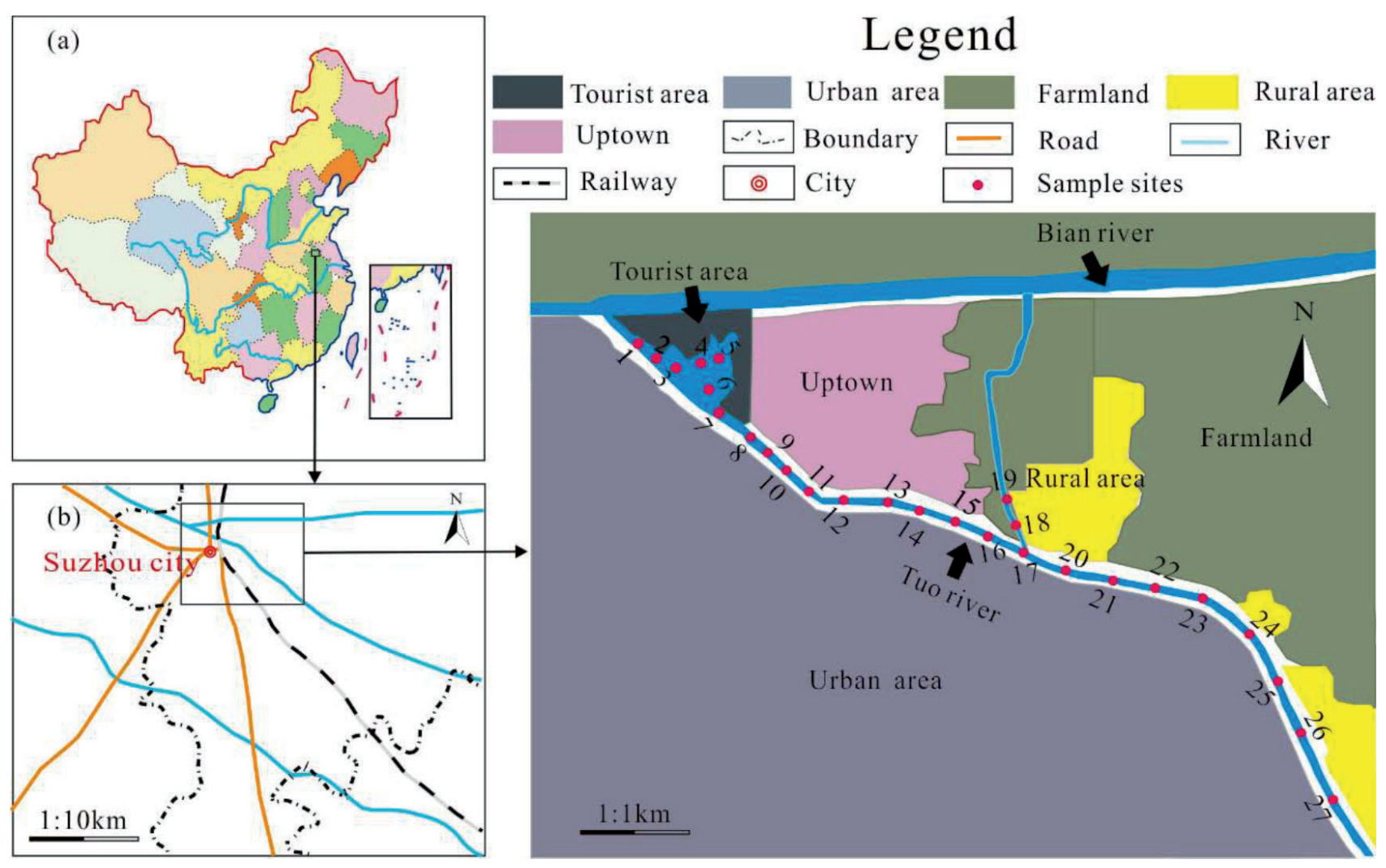

Fig. 1. Location and sampling sites in the Tuo River.

Shanghai, China) were used to measure the $\mathrm{pH}$ and dissolved oxygen (DO). After the water samples were taken back to the laboratory they were filtered through a $0.45 \mu \mathrm{m}$ filter, stored in a refrigerator at $4^{\circ} \mathrm{C}$ in the dark, and the relevant indicators were tested within 48 hours.

Total nitrogen (TN) was measured by potassium persulfate digestion UV spectrophotometric, total phosphorus (TP) determination using the ammonium molybdate spectrophotometric method, and determination of ammonia nitrogen $\left(\mathrm{NH}_{4}^{+}-\mathrm{N}\right)$ by salicylic acid spectrophotometry determination of the chemical oxygen demand (COD) dichromate method. Dissolved organic carbon (DOC) was measured by a total organic carbon analyzer (TOC-VWP, Shimadzu, Tokyo, Japan). The total amount of metal elements such as As, Fe, and $\mathrm{Cu}$ were tested by ICP-MS (Agilent 7900, California, USA). The accuracy of the above test results is controlled by using standard substances.

\section{Three-Dimensional Fluorescent Measurements and PARAFAC Modeling}

Fluorescence excitation/emission matrix (EEM) measurements were taken after the water sample temperature was consistent with room temperature. EEM were acquired using a fluorescence spectrometer (F-4600, Hitachi, Tokyo, Japan) with a $150 \mathrm{~W}$ ozonefree xenon arc lamp and a $1 \mathrm{~cm}$ quartz cell. EEM was collected at an excitation wavelength ranging from $220 \sim 450 \mathrm{~nm}$ at $5 \mathrm{~nm}$ increments and an emission wavelength ranging from $260 \sim 600 \mathrm{~nm}$ at $1 \mathrm{~nm}$ increments. Integration time and scan speed were set at $0.1 \mathrm{~s}$ and $3200 \mathrm{~nm} / \mathrm{s}$, respectively. Using Milli-Q ultrapure water as a blank, deducting Rayleigh scattering and Raman scattering, then Raman normalization with Raman peak of ultrapure water. The intensity of the fluorescent component is expressed in units of (R.U.) [17, 20].

Parallel factor analysis (PARAFAC) was performed on the three-dimensional fluorescence spectral data of the sample using Matlab2017b (MathWorks, USA) software in combination with DOMFluor Toolbox [21], and the residual scattering peak of the fluorescence spectrum was removed using the drEEM toolbox [22]. The number of fluorescent components was determined by minimum residual analysis, and the reliability of the results was discussed using a half-analysis.

\section{Fluorescence Spectral Index}

The fluorescence index (FI) was the ratio of the fluorescence intensities at the emission wavelengths of $450 \mathrm{~nm}$ and $500 \mathrm{~nm}$ at an excitation wavelength of $370 \mathrm{~nm}$ [23], which can be used to distinguish the source of the DOM. The biological index BIX is defined as the ratio of the fluorescence emission wavelength at $380 \mathrm{~nm}$ to $430 \mathrm{~nm}$ at an excitation wavelength of $310 \mathrm{~nm}$ [24]. The humification index (HIX) was as the ratio of intergrated emission integrated emission 
Table 1. Statistical analyses of water quality index, S.V(\%): Coefficient of variation.

\begin{tabular}{|c|c|c|c|c|c|c|c|c|c|c|c|c|}
\hline \multirow{2}{*}{ Parameters } & \multirow{2}{*}{ Unit } & \multicolumn{3}{|c|}{ A1 } & \multicolumn{3}{|c|}{ A2 } & \multicolumn{3}{c|}{ A3 } \\
\cline { 3 - 12 } & & Range & Mean & S.V(\%) & Range & Mean & S.V(\%) & Range & Mean & S.V(\%) & a(III) \\
\hline $\mathrm{pH}$ & - & $8.24 \sim 9.14$ & $\mathbf{8 . 8 4}$ & 3.08 & $8.3 \sim 8.92$ & $\mathbf{8 . 6 1}$ & 1.99 & $8.63 \sim 9.11$ & $\mathbf{8 . 8 6}$ & 1.43 & $6 \sim 9$ \\
\hline $\mathrm{DO}$ & $\mathrm{mg} / \mathrm{L}$ & $7.84 \sim 16.32$ & $\mathbf{1 0 . 8 1}$ & 23.14 & $10.68 \sim 16.03$ & $\mathbf{1 2 . 6 4}$ & 14.55 & $6.66 \sim 11.84$ & $\mathbf{9 . 5 8}$ & 16.99 & 5 \\
\hline $\mathrm{DOC}$ & $\mathrm{mg} / \mathrm{L}$ & $4.59 \sim 6.59$ & $\mathbf{5 . 0 8}$ & 12.57 & $4.21 \sim 5.38$ & $\mathbf{4 . 6 3}$ & 8.57 & $4.01 \sim 5.03$ & $\mathbf{4 . 4 8}$ & 7.93 & - \\
\hline $\mathrm{TN}$ & $\mathrm{mg} / \mathrm{L}$ & $1.76 \sim 3.30$ & $\mathbf{2 . 7 6}$ & 18.50 & $2.19 \sim 5.30$ & $\mathbf{2 . 9 0}$ & 29.99 & $1.22 \sim 8.49$ & $\mathbf{3 . 7 7}$ & 55.85 & 1.0 \\
\hline $\mathrm{TP}$ & $\mathrm{mg} / \mathrm{L}$ & $0.08 \sim 0.12$ & $\mathbf{0 . 1 0}$ & 12.98 & $0.07 \sim 0.10$ & $\mathbf{0 . 0 8}$ & 8.36 & $0.06 \sim 0.08$ & $\mathbf{0 . 0 7}$ & 9.09 & 0.2 \\
\hline $\mathrm{NH}_{4}{ }^{+} \mathrm{-N}$ & $\mathrm{mg} / \mathrm{L}$ & $0.17 \sim 0.29$ & $\mathbf{0 . 2 2}$ & 19.18 & $0.20 \sim 0.37$ & $\mathbf{0 . 2 7}$ & 21.03 & $0.29 \sim 0.87$ & $\mathbf{0 . 4 7}$ & 38.55 & 1.0 \\
\hline $\mathrm{COD}$ & $\mathrm{mg} / \mathrm{L}$ & $22.57 \sim 38.38$ & $\mathbf{2 8 . 0 5}$ & 20.52 & $15.80 \sim 31.60$ & $\mathbf{2 1 . 7 3}$ & 18.85 & $16.55 \sim 74.50$ & $\mathbf{3 1 . 8 3}$ & 51.09 & 20 \\
\hline $\mathrm{As}$ & $\mu \mathrm{g} / \mathrm{L}$ & $11.07 \sim 12.21$ & $\mathbf{1 1 . 8 5}$ & 2.91 & $9.32 \sim 11.01$ & $\mathbf{1 0 . 1 2}$ & 4.82 & $8.92 \sim 10.48$ & $\mathbf{9 . 7 3}$ & 5.86 & 50 \\
\hline
\end{tabular}

Note: a) the Class III standard of Chinese standard of surface water environment quality (GB3838-2002)

intensity between 435 and $480 \mathrm{~nm}$ to that between 300 and $345 \mathrm{~nm}$ at an excitation wavelength of $254 \mathrm{~nm}$ [25]. $\mathrm{Fn}(280)$ is the maximum fluorescence intensity of the emission wavelength between 340 and $360 \mathrm{~nm}$ when the excitation wavelength is $280 \mathrm{~nm}$, which can reflect the relative concentration level of protein-like substances [26]. $\mathrm{Fn}(355)$ is the maximum fluorescence intensity at an excitation wavelength of $355 \mathrm{~nm}$ and an emission
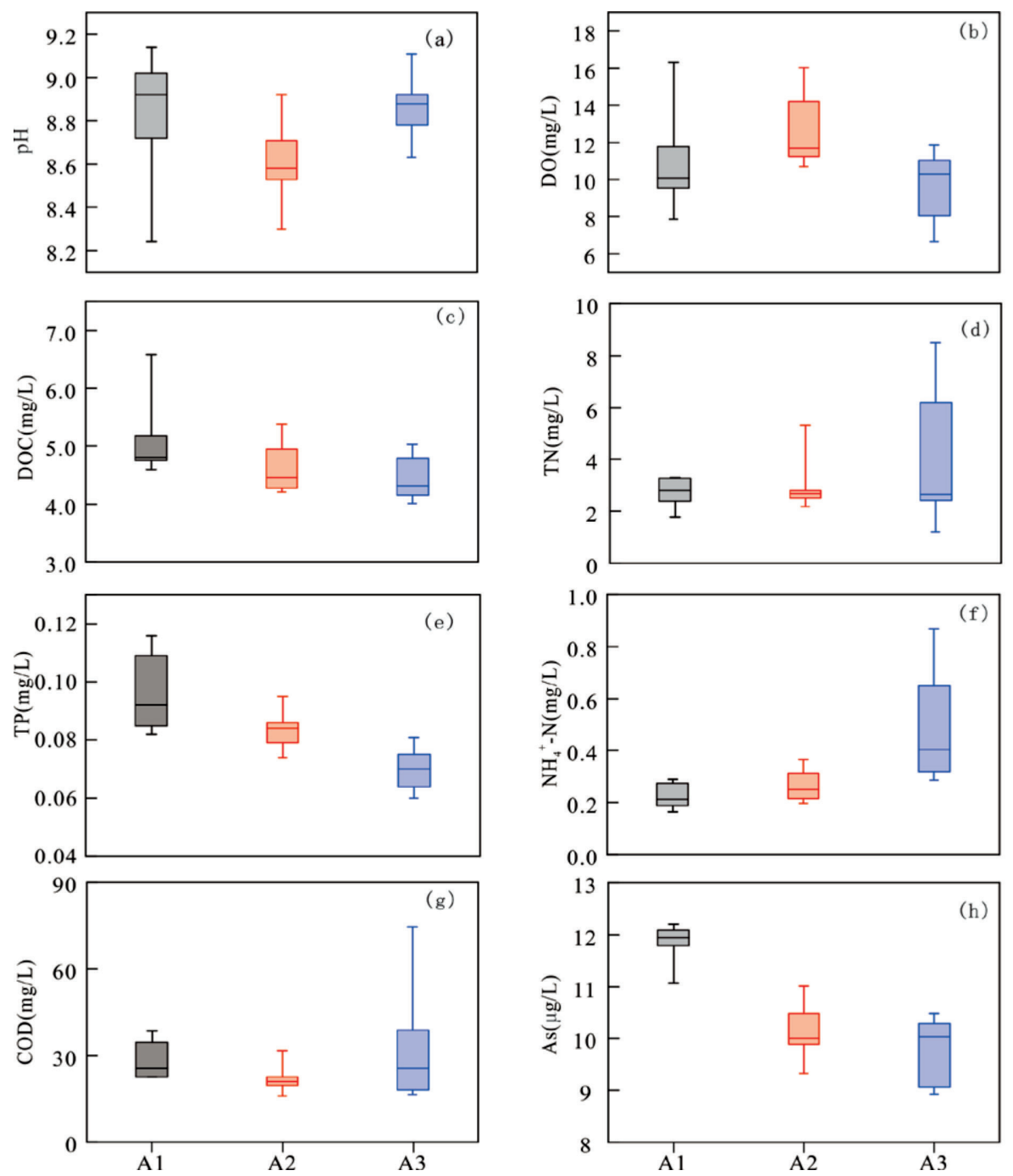

Fig. 2. Water quality parameters of the upper, middle and lower reaches of the Tuo River. 
wavelength between 440 and $470 \mathrm{~nm}$, representing the relative concentration level of humic-like substances [26].

\section{Results and Discussion}

\section{Water Quality Parameter Statistics and Analysis}

The statistical analysis results of the water quality parameters ( $\left.\mathrm{pH}, \mathrm{DO}, \mathrm{DOC}, \mathrm{TN}, \mathrm{TP}, \mathrm{NH}_{4}^{+}-\mathrm{N}, \mathrm{COD}, \mathrm{As}\right)$ of the upper reaches of the Tuo River Tourist affected area (A1), the mid-stream residential affected area (A2), and the downstream agricultural affected area (A3) are shown in Table 1, which lists the eigenvalues for each parameter along with the Chinese standard of surface water environment quality (GB3838-2002). Table 1 lists that the mean concentrations of each water quality parameter, which showed that the values of $\mathrm{TN}$, $\mathrm{NH}_{4}{ }^{+} \mathrm{N}$ and COD were higher in the area of $\mathrm{A} 3$, the contents of $\mathrm{TN}, \mathrm{NH}_{4}^{+}-\mathrm{N}$ and COD are mainly caused by man-made pollution [6]. It is suggested that area A3 is greatly affected by human activities. The water quality parameters will be further analyzed in combination with the box diagram (Fig. 2).

Fig. 2(a-h) shows the distribution of water quality parameters $\left(\mathrm{pH}, \mathrm{DO}, \mathrm{DOC}, \mathrm{TN}, \mathrm{TP}, \mathrm{NH}_{4}^{+}-\mathrm{N}, \mathrm{COD}\right.$, As) of the upstream tourist affected area (A1), midstream residential affected area (A2), and downstream agricultural affected area (A3) of the Tuo River. As shown in Fig. 2a), the values of $\mathrm{pH}$ vary from 8.24 to 9.14 with an average value of 8.78 , which is slightly alkaline water. The $\mathrm{pH}$ value of the river water in the areas of $\mathrm{A} 1$ and $\mathrm{A} 3$ are higher than that in the A2 area, and the $\mathrm{pH}$ values of sampling points No. 2, 5 and 27 exceeds the allowable limit set by the Chinese Surfer Water Quality Standard (GB 3838-2002), which may be related to the accumulation of contaminants. As shown in Fig. 2b), DO values vary between 6.66 to $16.32 \mathrm{mg} / \mathrm{L}$ with an average value of $10.92 \mathrm{mg} / \mathrm{L}$, and the DO content in the midstream region (A2) is relatively high, related to the floating plants in the river. The concentration of DOC ranges from 4.01 to $6.59 \mathrm{mg} / \mathrm{L}$, with an average of $4.68 \mathrm{mg} / \mathrm{L}$. In the upstream (A1) and midstream (A2) to the downstream (A3) of the Tuo River, the content of DOC in the river decreased in turn (Fig. 2c). The upstream of A1 is connected to the Bian River, and its surrounding area was farmland. Therefore, we speculated that the DOC content in the Tuo is mainly influenced by the Bian. Previous studies have reported that agriculture was an important source of DOC to aquatic environments $[9,17]$

The values of TN vary from 1.22 to $8.49 \mathrm{mg} / \mathrm{L}$, with a mean of $3.22 \mathrm{mg} / \mathrm{L}$. The content of $\mathrm{TN}$ for all water samples exceeded the surface water quality standards value listed as class III of $1 \mathrm{mg} / \mathrm{L}$ (GB 3838-2002). As shown in Fig. 2d), the content of $\mathrm{TN}$ in downstream (A3) river water is significantly higher than that in upstream (A1) and midstream (A2), probably due to the relatively large area of downstream agricultural land and the excessive use of nitrogenous fertilizer [27]. The concentration of TP ranges from 0.06 to $0.116 \mathrm{mg} / \mathrm{L}$, with an average value of $0.082 \mathrm{mg} / \mathrm{L}$. The concentrations of TP for each sampling point all met the Class III water standard (GB 3838-2002). As shown in Fig. 2c), the distribution characteristics of TP are as follows: upstream (A1) to midstream (A2) and downstream (A3), $\mathrm{NH}_{4}^{+}-\mathrm{N}$ ranges from 0.17 to $0.87 \mathrm{mg} / \mathrm{L}$ with an average of $0.34 \mathrm{mg} / \mathrm{L}$, which are consistent with the Class III water standard (GB 38382002). The distribution characteristics of $\mathrm{NH}_{4}^{+}-\mathrm{N}$ in the Tuo (Fig. 2f) are like those of $\mathrm{TN}$, that is, the content of $\mathrm{NH}_{4}^{+}-\mathrm{N}$ in the downstream (A3) water is the highest, which is the result of farmland environmental impact.

The COD concentration of the Tuo is $15.8 \sim 74.5 \mathrm{mg} / \mathrm{L}$, and the average value is $27.49 \mathrm{mg} / \mathrm{L}$. Only the COD value of water sample Nos. 21 and 22 in area A3 exceeds the surface water quality V standard (GB 38382002), and there is a rainwater pipe network near the sampling point that is affected by the initial rainwater. As shown in Fig. 2g), there is no significant difference in the COD values of the environmental impact zones in the Tuo. The values of As in the Tuo ranged from 8.35 to $11.43 \mu \mathrm{g} / \mathrm{L}$, with an average of $9.75 \mu \mathrm{g} / \mathrm{L}$. The values of As in the upstream (A1) river water were relatively large (Fig. 2h), but it met the Class III water standard (GB 3838-2002).

Principal component analysis (PCA) was applied to the water quality parameters $(\mathrm{pH}, \mathrm{DO}, \mathrm{DOC}, \mathrm{TN}$, TP, $\mathrm{NH}_{4}^{+}-\mathrm{N}, \mathrm{COD}, \mathrm{As}$ ) from the Tuo (Fig. 3). The first $(\mathrm{PC} 1,34.97 \%)$ and second $(\mathrm{PC} 2,21.63 \%)$ principal components accounted for $56.61 \%$ of the overall data variable. $\mathrm{TN}, \mathrm{NH}_{4}^{+}-\mathrm{N}$, and $\mathrm{COD}$ has a relatively high positive load with the first principal component, while As and TP had high negative loading. All water

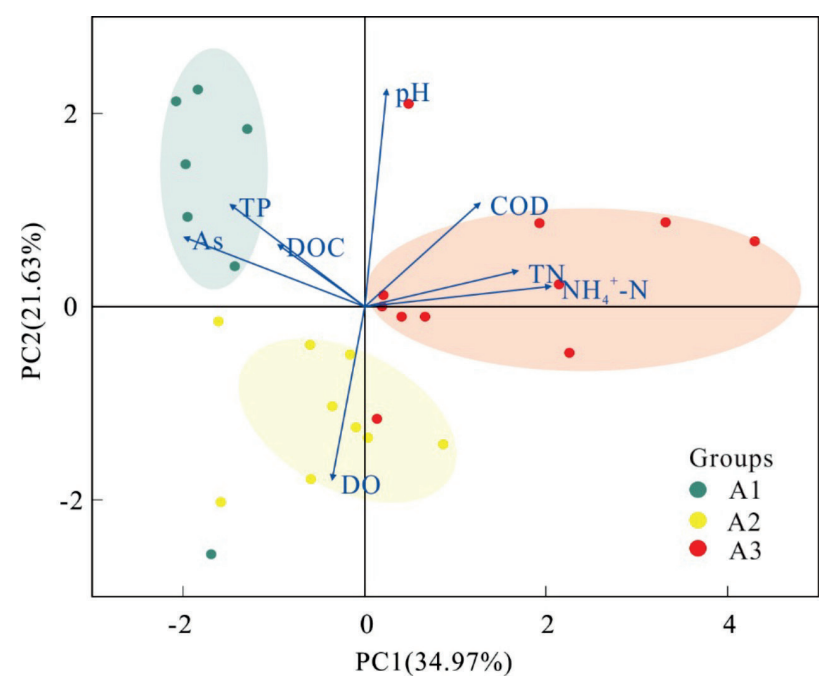

Fig. 3. Principal component analysis (PCA) of the water quality parameters (DO, DOC, TN, TP, $\left.\mathrm{NH}_{4}^{+}-\mathrm{N}, \mathrm{COD}, \mathrm{AS}, \mathrm{pH}\right)$ of the upper (A1), middle (A2) and lower (A3) reaches of the Tuo River. 


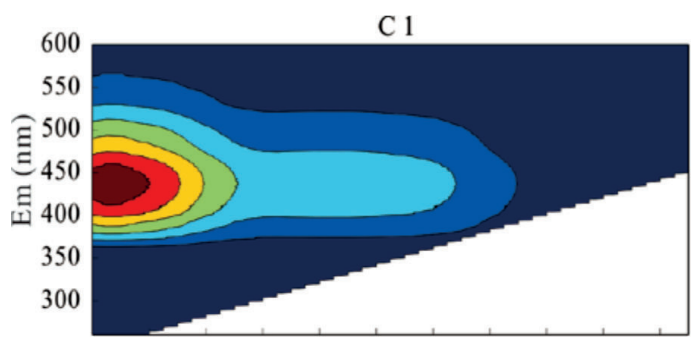

$\begin{array}{lllllllllll}240 & 260 & 280 & 300 & 320 & 340 & 360 & 380 & 400 & 420 & 440\end{array}$ Ex (nm)

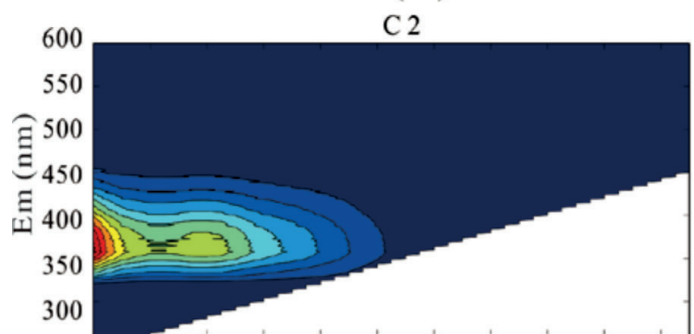

$240 \quad 260 \quad 280300 \quad 320 \quad 340 \quad 360 \quad 380 \quad 400 \quad 420 \quad 440$ Ex $(\mathrm{nm})$

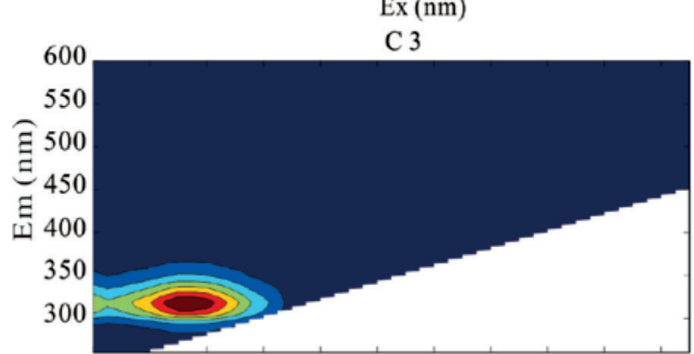

$240260280300320340 \quad 360380 \quad 400 \quad 420440$ $\operatorname{Ex}(\mathrm{nm})$

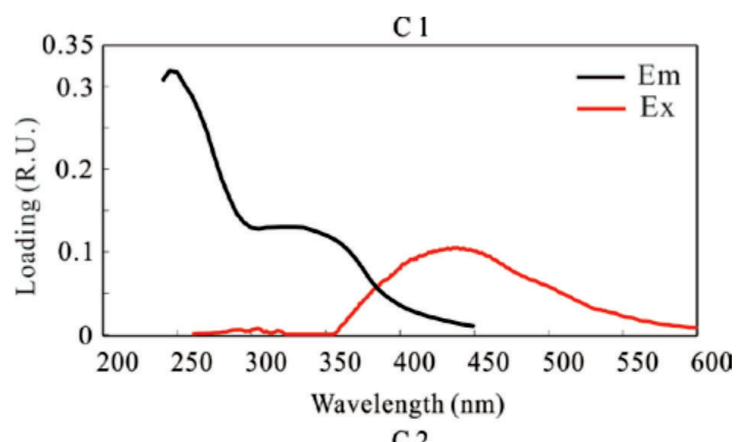

$\mathrm{C} 2$

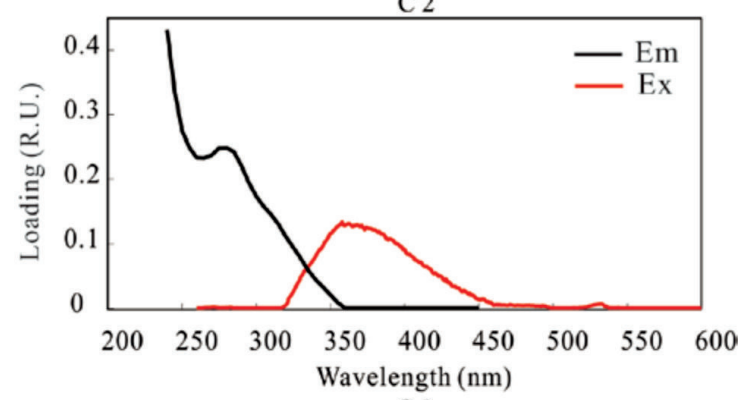

C 3

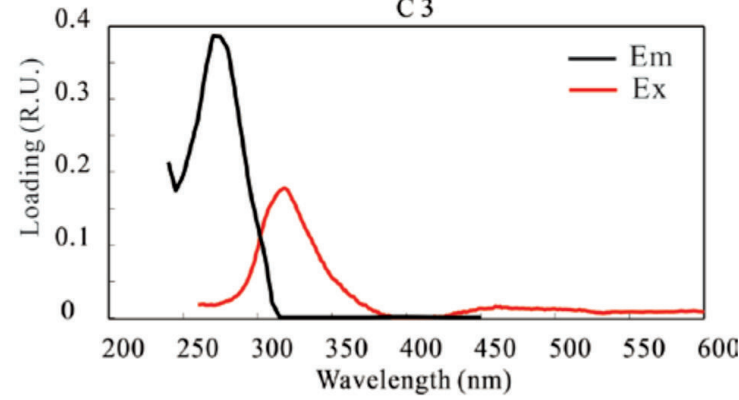

Fig. 4. Three-dimensional fluorescence spectra and maximum excitation/wavelength distribution of components of DOM in the Tuo River.

samples from the area of A3 clustered on the positive side of PC1. PC2 demonstrated relatively high positive loadings for $\mathrm{pH}$ and TP. Most of the water samples from the area of A1 were clustered on the positive side of PC2. The water sample in the middle (A2) is located in the lower-left corner of Fig. 3. Principal component analysis results show that due to the different ecological environment around the water body, the water quality parameters of different environmental impact areas are different, which will inevitably affect the composition of DOM in water.

\section{Characteristics and Source Analysis of DOM}

Fluorescence Components in the Tuo River

In this study, by using parallel factor analysis (PARAFAC), three fluorescent components were derived from the EEM data of the Tuo River: terrestrial humiclike components (C1), tryptophan-like components (C2) and Tyrosine-like components (C3). Previous studies found that DOM in the soils and forest watersheds was dominated by humic-like components (C1), tryptophanlike (C2) and Tyrosine-like components (C3) often used as important markers of septic and wastewater treatment plant discharge [17, 19]. The corresponding emission and excitation values of the three components are shown in (Fig. 4). Table 2 shows the wavelengths of the excitation and emission peaks of each component and matches with the fluorescent components in the literature of the OpenFluor online spectral library (Tucker's congruence coefficients of 0.95 for excitation and emission spectra). The matching numbers of $\mathrm{C} 1$, $\mathrm{C} 2$, and $\mathrm{C} 3$ are 32,14 , and 15 , respectively.

Fig. 5 shows the values of fluorescence maximum (R.U) for fluorescence components in different environmental impact zones of the Tuo. As shown in Fig. 5a), the fluorescence intensity of the $\mathrm{Cl}$ component in regions $\mathrm{A} 1$ and $\mathrm{A} 3$ is significantly higher than that of region A2. Some studies have shown that the spatial distribution of DOM in water bodies is closely related to land use types [28]. C1 is humic-like substance produced by the terrestrial plant and soil microbial degradation [29]. In particular, the use of organic fertilizers in areas $\mathrm{A} 1$ and $\mathrm{A} 3$ often results in a large amount of humiclike substances. C2 is a tryptophan-like substance [14, 30], which is sensitive to environmental changes and an excellent marker of anthropogenic activities [17, 31]. The analysis of water quality parameters of the Tuo shows that eutrophication of the upper reaches of 
Table 2. Spectral characteristics of Ex/Em of three fluorescent components.

\begin{tabular}{|c|c|c|c|}
\hline Component & Ex/Em & Probable origin & Number of matches $^{\mathrm{b}}$ \\
\hline $\mathrm{C} 1$ & $245(335)^{\mathrm{a}} / 436$ & Terrestrial humic-like substances & 14 \\
\hline $\mathrm{C} 2$ & $<240(275)^{\mathrm{a}} / 358$ & Tryptophane-like substances & 15 \\
\hline $\mathrm{C} 3$ & $<240(270)^{\mathrm{a}} / 319$ & Tyrosine-like substances & 14 \\
\hline
\end{tabular}

Notes: a) excitation wavelengths in parentheses represent secondary peak; b) www.openfluor.org
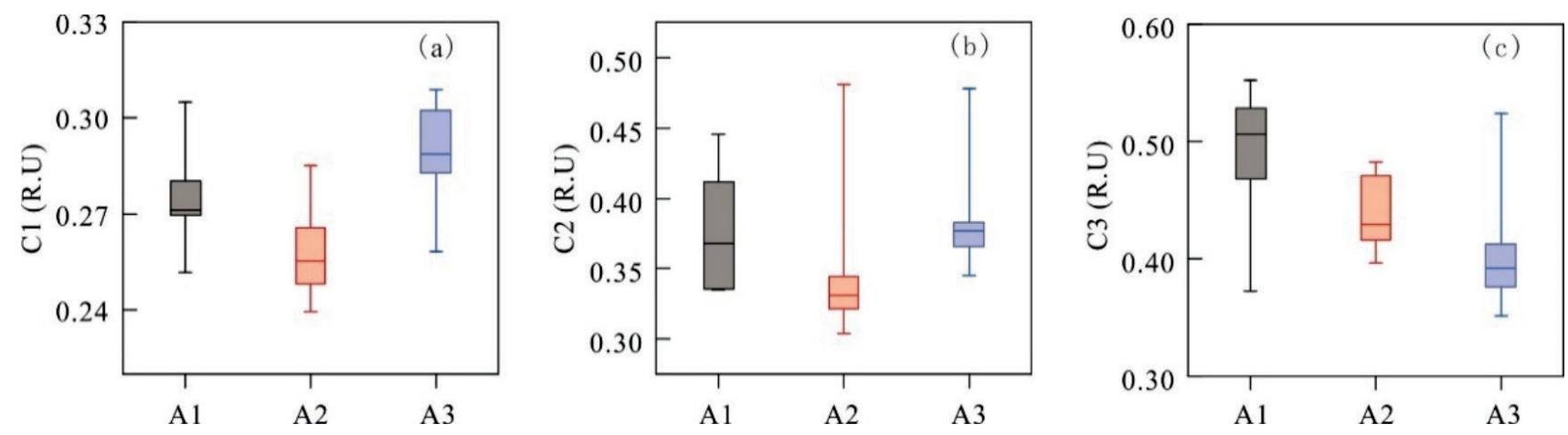

Fig. 5. Box plot comparisons of PARAFAC components among the areas of A1, A2, A3.

the Tuo (A1) and downstream (A3) is relatively serious, and the microbial activity in the water body is relatively strong, which makes the $\mathrm{C} 2$ content in the regional $\mathrm{A} 1$ and A3 rivers higher (Fig. 5b). C3 is a tyrosine-like substance, and its content decreases sequentially along the upstream and downstream (Fig. 5c). The content of C3 may be related to the direct interference of microorganism activities. We suspect that its content is related to the eutrophication degree of the river.

Fluorescence parameters (FI, BIX, HIX) have a good indication of the source of DOM [24, 32], so the fluorescence parameters are used to further analyze the spectral characteristics and sources of DOM in water bodies under different environmental influence areas. FI (fluorescence index) as an indicator of DOM source [33], when $\mathrm{FI}<1.4$ means that it is mainly derived from terrestrial or soil input; when FI $>1.9$, it means that is mainly from autochthonous. When $1.4<\mathrm{FI}<1.9$, it indicates that it is affected by both terrestrial and autochthonous sources. In the present study, the value of FI range from 1.79 2.53, only the No. 22 water sample FI value (1.79) is between 1.4 and 1.9, which were affected by initial rain. As shown in Fig. 6a), indicating DOM sources were autochthonous.

To further clarify the source of DOM, the biological index (BIX) and the humification index (HIX) were cited [24]. When BIX $>1$, it shows strong autochthonous source characteristics, and DOM is mainly produced by biological bacteria. It can be seen from Fig. 6b) that the BIX values of the water samples in each zone are all greater than 1.0, indicating that the DOM has strong autochthonous source characteristics in this study area. HIX is mainly used to characterize the degree of humification of humic-like substances produced
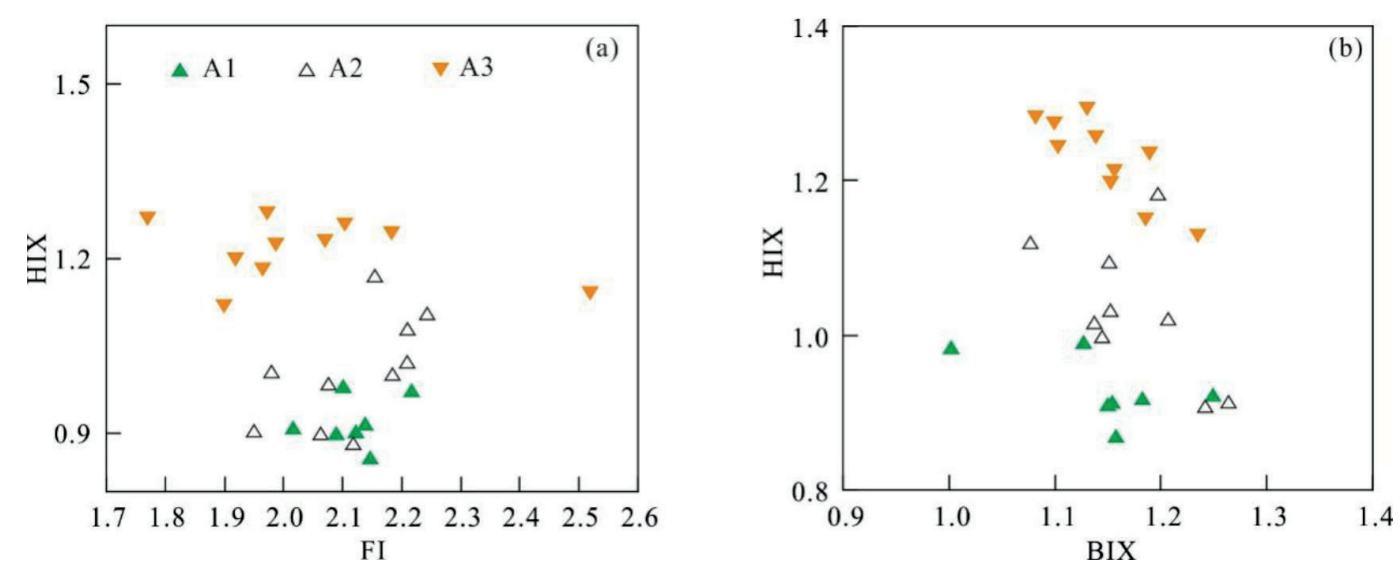

Fig. 6. Distribution of the fluorescence index in the upper (A1), middle (A2) and lower (A3) reaches of the Tuo River. 
Table 3. Pearson's coefficients between selected fluorescence indices and water quality in the Tuo River.

\begin{tabular}{|c|c|c|c|c|c|c|c|c|}
\hline & $\mathrm{DO}$ & $\mathrm{pH}$ & $\mathrm{DOC}$ & $\mathrm{COD}$ & $\mathrm{TP}$ & $\mathrm{TN}$ & $\mathrm{NH}_{4}^{+}-\mathrm{N}$ & $\mathrm{As}$ \\
\hline $\mathrm{C} 1$ & $-0.500^{* *}$ & $0.538^{* *}$ & -0.093 & $0.387^{*}$ & -0.117 & 0.200 & $\mathbf{0 . 6 6 3}^{* *}$ & -0.270 \\
\hline $\mathrm{C} 2$ & -0.187 & 0.157 & 0.219 & 0.344 & -0.072 & 0.278 & $0.470^{* *}$ & 0.062 \\
\hline $\mathrm{C} 3$ & $0.453^{*}$ & -0.056 & $0.413^{*}$ & -0.017 & $\mathbf{0 . 4 5 9}^{*}$ & -0.072 & -0.182 & $\mathbf{0 . 6 0 5}^{* *}$ \\
\hline Fn280 & -0.123 & $0.459^{*}$ & 0.181 & 0.032 & $\mathbf{0 . 5 9 5}^{* *}$ & -0.051 & -0.146 & $0.435^{*}$ \\
\hline Fn355 & $-0.446^{*}$ & $\mathbf{0 . 5 4 7}^{* *}$ & -0.260 & 0.346 & 0.213 & 0.254 & 0.081 & 0.022 \\
\hline
\end{tabular}

$* \mathrm{p}<0.05, * * \mathrm{p}<0.01$

by terrestrial sources in DOM. When $10<\mathrm{HIX}<16$, it indicates that DOM has strong humification characteristics, mainly based on terrestrial input. When HIX $<4$, it indicates that DOM has weak humification characteristics, mainly autochthonous [24]. In this study, the HIX values (Fig. 6) of all sampling points in the Tuo River ranged from 0.89 to 1.3 , indicating that the DOM in the watershed of the environmental impact areas of the Tuo River is mainly derived from aquatic bio-metabolism or aquatic bacteria.

\section{Correlation between General Water Quality Indices and PARAFAC Components}

Correlation coefficients between PARAFAC components $(\mathrm{C} 1, \mathrm{C} 2, \mathrm{C} 3)$, DOM fluorescent indices (Fn (280), Fn (355)) and water quality parameters $(\mathrm{pH}$, DO, DOC, TN, TP, $\mathrm{NH}_{4}^{+}-\mathrm{N}, \mathrm{COD}, \mathrm{As}$ ) were calculated and the results are shown in Table 3. Their relationship with the correlation coefficients was evaluated using Pearson's correlation coefficient (r).

Due to the variability of human activities and landuse types, river water quality is deteriorating and it is difficult to analyze the sources of pollutants through conventional water quality indicators. Parallel factor analysis can effectively compensate for the lack of conventional indicators in the indication of pollutant

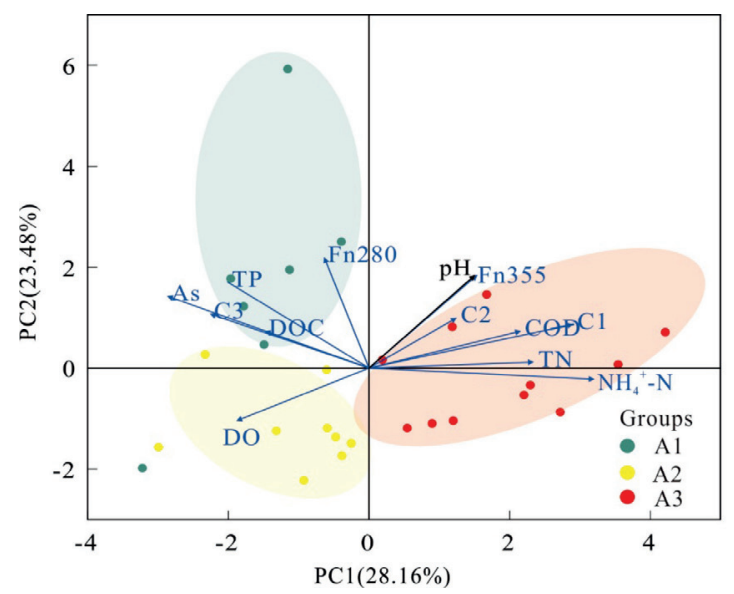

Fig. 7. Principal component analysis (PCA) of the water quality parameters and PARAFAC components. sources [11, 20]. As shown in Table 3, the water quality parameters $\mathrm{NH}_{4}^{+}-\mathrm{N}, \mathrm{TP}, \mathrm{pH}, \mathrm{DO}$ and As have a good correlation with $\mathrm{C} 1, \mathrm{C} 2$, and $\mathrm{C} 3$, indicating that the parallel factor component can be used as an indicator of water quality parameters. The fluorescence parameters $\mathrm{Fn}(280)$ and $\mathrm{Fn}(355)$ have a good correlation with TP and $\mathrm{pH}$, respectively, indicating that the fluorescence parameters can be used as indicators of $\mathrm{TP}$ and $\mathrm{pH}$ in the surface aquatic environment. There is a weak correlation between TN, COD and DOC, and fluorescence components and fluorescence index, which may be related to the complexity of water quality parameters of various sources in water ecosystems [6].

In order to determine the comprehensive water quality of the water samples in each area, the principal component analysis of each water quality parameter $\left(\mathrm{pH}, \mathrm{DO}, \mathrm{DOC}, \mathrm{TN}, \mathrm{TP}, \mathrm{NH}_{4}^{+}-\mathrm{N}, \mathrm{COD}, \mathrm{As}\right)$, fluorescence component $(\mathrm{C} 1, \mathrm{C} 2, \mathrm{C} 3)$ and fluorescence index $(\operatorname{Fn}(280), \operatorname{Fn}(355))$ is shown in Fig. 7. The first and two principal components (PC1 and PC2) can account for $28.16 \%$ and $23.48 \%$ of the total variables, respectively. The scores of $\mathrm{PC} 1$ and $\mathrm{PC} 2$ of sampling points in environmental impact areas A1, A2 and A3 further illustrate the different water quality conditions in areas $\mathrm{A} 1, \mathrm{~A} 2$ and $\mathrm{A} 3$. $\mathrm{PC} 1$ was strongly positively correlated with $\mathrm{Cl}, \mathrm{TN}, \mathrm{NH}_{4}^{+}-\mathrm{N}$ and $\mathrm{COD}$. The sampling points of the A3 area are distributed on the positive side of $\mathrm{PC1}$. It is suggested that agricultural region $\mathrm{A} 3$ has higher content of $\mathrm{C} 1, \mathrm{TN}, \mathrm{NH}_{4}^{+}-\mathrm{N}$ and COD than other two regions (A1 and A2). Some studies have shown that there are more nitrogenous pollutants in rivers in agricultural areas [9], and the A3 region is mainly affected by agricultural non-point sources, resulting in more TN content. $\mathrm{PC} 2$ is characterized by indices $(\mathrm{C} 3, \mathrm{TP}, \mathrm{DOC})$ relating direct interference of human activities (such as domestic sewage discharge), Moreover, the relationship between the PC2 and A1 regional sampling points is relatively close, indicating that the water body in area A1 is greatly affected by human activities.

\section{Conclusions}

(1) Through the analysis of the water quality parameters of the Tuo River in different environmental 
impact areas - upstream tourism affected area (A1), midstream residential affected area (A2), and downstream agricultural affected area (A3) - the results show that: the upstream affected area of (A1) and downstream agricultural-affected areas (A3) have relatively poor water quality.

(2) Parallel factor analysis was used to analyze the components of DOM in different environmental impact zones, and three components were obtained: humic-like substances (C1), tryptophan-like substances (C2) and tyrosine-like substances (C3). The content of $\mathrm{C} 1$ and $\mathrm{C} 2$ components in area $\mathrm{A} 1$ and $\mathrm{A} 3$ is higher, and the $\mathrm{C} 3$ content decreases in sequence along the river flow direction. The results of the fluorescence index analysis show that the characteristics of DOM self-generated source in the water bodies of each environmental impact area of the Tuo are obvious.

(3) Correlation and principal component analysis results show that the tourism-affected area (A1) is directly interfered with by human activities, and the environmental carrying capacity of the tourist area should be fully considered. The agricultural-affected area (A3) has a great impact on the water quality of the river, and the prevention and control of agricultural non-point source pollution should be strengthened.

\section{Acknowledgements}

This research was funded by the National Natural Science Foundation of China, grant number 41773100, funded by the postgraduate innovation fund project of Anhui University of Science and Technology(2019CX2006), the Provincial Natural Science Research Foundation of Colleges and Universities in Anhui Province (KJ2019A0667), the Key Natural Science Research Projects of Anhui Provincial Education Department (KJ2018A0445), as a research project of Huaibei Mining Group Co. (2019) and as a research project of Wanbei Coal-Electricity Group Co. Ltd (2019).

\section{Conflict of Interest}

The authors declare no conflict of interest.

\section{References}

1. XIAO M., WU F., YI Y., HAN Z., WANG Z. Optical Properties of Dissolved Organic Matter and Controlling Factors in Dianchi Lake Waters. Water, 11 (10), 1967, 2019.

2. CHEN H., ZHENG B. Sources of fluorescent dissolved organic matter in high salinity seawater (Bohai Bay, China). Environmental Science and Pollution Research, 20 (3), 1762, 2013.

3. LIU W., ZHANG L., LIU P., QIN,X., SHAN X., YAO $\mathrm{X}$. FDOM conversion in karst watersheds expressed by three-dimensional fluorescence spectroscopy. Water, 10 (10), 1, 2018.

4. CHEN W., WESTERHOFF P., LEENHEER J. A., BOOKSH K. Fluorescence excitation - Emission matrix regional integration to quantify spectra for dissolved organic matter. Environmental Science \& Technology, 37 (24), 5701, 2003.

5. AIKEN G.R., HSU-KIM H., RYAN J.N. Influence of Dissolved Organic Matter on the Environmental Fate of Metals, Nanoparticles, and Colloids. Environmental Science \& Technology, 45 (8), 3196, 2011.

6. TANG J., LI X., CAO C., LIN M., QIU Q., XU Y., REN Y. Compositional variety of dissolved organic matter and its correlation with water quality in peri-urban and urban river watersheds. Ecological Indicators, 104, 459, 2019.

7. WILLIAMS C.J., FROST P.C., MORALES-WILLIAMS A.M., LARSON J.H., RICHARDSON W.B., CHIANDET A.S., XENOPOULOS M.A. Human activities cause distinct dissolved organic mattercomposition across freshwater ecosystems. Global Change Biology, 22 (2), 613, 2016.

8. ZHOU P., HUANG J., PONTIUS JR. R.G., HONG H. New insight into the correlations between land use and water quality in a coastal watershed of China: Does point source pollution weaken it. Science of the Total Environment, 543 (A), 591, 2016.

9. GRAEBER D., GELBRECHT J., PUSCH M.T., ANLANGER C., VON SCHILLER D. Agriculture has changed the amount and composition of dissolved organic matter in Central European headwater streams. Science of the Total Environment, 438, 435, 2012.

10. GUECKER B., SILVA R.R.C.S., GRAEBER D., MONTEIRO J.A.F., BOECHAT I.G. Urbanization and agriculture increase exports and differentially alter elemental stoichiometry of dissolved organic matter (DOM) from tropical catchments. Science of the Total Environment, 550, 785, 2016.

11. FASCHING C., WILSON H.F., D'AMARIO S.C., XENOPOULOS M.A. Natural Land Cover in Agricultural Catchments Alters Flood Effects on DOM Composition and Decreases Nutrient Levels in Streams. Ecosystems, 22 (7), 1530, 2019.

12. BU H., SONG X., ZHANG Y. Using multivariate statistical analyses to identify and evaluate the main sources of contamination in a polluted river near to the Liaodong Bay in Northeast China. Environmental Pollution, 245, 1058, 2019.

13. WANG X., ZHANG F., KUNG H.T.E., GHULAM A., TRUMBO A.L., YANG J., JING Y. Evaluation and estimation of surface water quality in an arid region based on EEM-PARAFAC and 3D fluorescence spectral index: A case study of the Ebinur Lake Watershed, China. Catena, 155, 62, 2017.

14. YAMASHITA Y., BOYER J.N., JAFFE R. Evaluating the distribution of terrestrial dissolved organic matter in a complex coastal ecosystem using fluorescence spectroscopy. Continental Shelf Research, 66, 136, 2013.

15. PELEATO N.M., LEGGE R.L., ANDREWS R.C. Investigation of fluorescence methods for rapid detection of municipal wastewater impact on drinking water sources. Spectrochimica Acta part A-Molecular and Biomolecular Spectroscopy, 171, 104, 2017.

16. ISHII S.K.L., BOYER T.H. Behavior of Reoccurring PARAFAC Components in Fluorescent Dissolved Organic Matter in Natural and Engineered Systems: A Critical 
Review. Environmental Science \& Technology, 46 (4), 2006, 2012

17. YANG X., YU X., CHENG J., ZHENG R., WANG K., DAI Y., CHOW A. T. Impacts of land-use on surface waters at the watershed scale in southeastern China: Insight from fluorescence excitation-emission matrix and PARAFAC. Science of the Total Environment, 627, 647, 2018.

18. KULKARNI H., MLADENOV N., DATTA S. Effects of acidification on the optical properties of dissolved organic matter from high and low arsenic groundwater and surface water. Science of the Total Environment, 653, 1326, 2019.

19. SEPP M., KOIV T., NOGES P., NOGES T. The role of catchment soils and land cover on dissolved organic matter (DOM) properties in temperate lakes. Journal of Hydrology, 570, 281, 2019.

20. LAWAETZ A.J., STEDMON C.A. Fluorescence Intensity Calibration Using the Raman Scatter Peak of Water. Applied Spectroscopy, 63 (8), 936, 2009.

21. STEDMON C.A., BRO R. Characterizing dissolved organic matter fluorescence with parallel factor analysis: a tutorial. Limnology and Oceanography-Methods, 6, 572, 2008.

22. ZEPP R.G., SHELDON W.M., MORAN M.A. Dissolved organic fluorophores in southeastern US coastal waters: correction method for eliminating Rayleigh and Raman scattering peaks in excitation-emission matrices. Marine Chemistry, 89 (1-4), 15, 2004.

23. PAINTER S.C., LAPWORTH D.J., WOODWARD E.M.S., KROEGER S., EVANS C.D., MAYOR D.J., SANDERS, R.J. Terrestrial dissolved organic matter distribution in the North Sea. Science of the Total Environment, 630 (1), 630, 2018.

24. HUGUET A., VACHER L., RELEXANS S., SAUBUSSE S., FROIDEFOND J.M., PARLANTI E. Properties of fluorescent dissolved organic matter in the Gironde Estuary. Organic Geochemistry, 40 (6), 706, 2009.
25. ZSOLNAY A., BAIGAR E., JIMENEZ M., STEINWEG B., SACCOMANDI F. Differentiating with fluorescence spectroscopy the sources of dissolved organic matter in soils subjected to drying. Chemosphere, 38 (1), 45, 1999.

26. ZHANG Y., LIU M., QIN B., FENG S. Photochemical degradation of chromophoric-dissolved organic matter exposed to simulated UV-B and natural solar radiation. Hydrobiologia, 627 (1), 159, 2009.

27. DALEY M., MCDOWELL W. Landscape controls on dissolved nutrients, organic matter and major ions in a suburbanizing watershed. AGU Fall Meeting Abstracts, 2010.

28. PETRONE K.C., FELLMAN J.B., HOOD E., DONN M.J., GRIERSON P.F. The origin and function of dissolved organic matter in agro-urban coastal streams. Journal of Geophysical Research-Biogeosciences, 116, 2011.

29. YANG L., CHEN W., ZHUANG W.-E., CHENG Q., LI W., WANG H., LIU M. Characterization and bioavailability of rainwater dissolved organic matter at the southeast coast of China using absorption spectroscopy and fluorescence EEM-PARAFAC. Estuarine Coastal and Shelf Science, 217, 45, 2019.

30. ZHU W.Z., ZHANG H.H., ZHANG J., YANG G.P. Seasonal variation in chromophoric dissolved organic matter and relationships among fluorescent components, absorption coefficients and dissolved organic carbon in the Bohai Sea, the Yellow Sea and the East China Sea. Journal of Marine Systems, 180, 9, 2018.

31. BAKER A., INVERARITY R. Protein-like fluorescence intensity as a possible tool for determining river water quality. Hydrological Processes, 18 (15), 2927, 2004.

32. JIANG T., BRAVO A.G., SKYLLBERG U., BJORN E., WANG D., YAN H., GREEN N. W. Influence of dissolved organic matter (DOM) characteristics on dissolved mercury $(\mathrm{Hg})$ species composition in sediment porewater of lakes from southwest China. Water Research, 146, 146, 2018. 